RONCONI, Diego Richard. BRAGA, Natan Ben-Hur. A propriedade de quotas societárias: alguns de seus desdobramentos jurídicos nas relações privadas. Revista Eletrônica Direito e Política, Programa de Pós-Graduação Stricto Sensu em Ciência Jurídica da UNIVALI, Itajaí, v.11, n.1, $1^{\circ}$ quadrimestre de 2016. Disponível em: www.univali.br/direitoepolitica - ISSN 1980-7791.

\title{
A PROPRIEDADE DE QUOTAS SOCIETÁRIAS: ALGUNS DE SEUS DESDOBRAMENTOS JURÍDICOS NAS RELAÇÕES PRIVADAS
}

\author{
LA PROPIEDAD DE LAS CUOTAS SOCIETARIAS: ALGUNOS DE SUS \\ DESDOBLAMIENTOS JURÍDICOS EN LAS RELACIONES PRIVADAS
}

\author{
Diego Richard Ronconi ${ }^{1}$ \\ Natan Ben-Hur Braga ${ }^{2}$
}

SUMÁRIO: Introdução; 1. O Capital Social das empresas e a formação das Quotas Societárias; 2. O Princípio da Autonomia Patrimonial da Pessoa Jurídica; 3. As Quotas Societárias no âmbito de algumas disciplinas jurídicas civis e empresariais; 3.1. As quotas no direito das obrigações e contratos; 3.2. As quotas no direito societário; 3.3. As quotas no direito de família e sucessões; Considerações finais; Referências

\section{RESUMO}

O objeto do presente trabalho é realizar um breve estudo acerca da propriedade das quotas societárias. O objetivo geral é identificar o conceito de quota societária, bem como estabelecer reflexões e desdobramentos da condição de ser proprietário de quotas societárias em algumas disciplinas jurídicas no âmbito do direito civil (obrigações, contratos, família e sucessões) e empresarial (direito societário). Os objetivos específicos da pesquisa, confirmados com o estudo, identificaram alguns direitos de ordem pessoal e patrimonial do titular das quotas. Dentre os direitos de ordem patrimonial, identificou-se a distribuição de lucros societários, os quais poderão ser desproporcionais à participação do sócio na sociedade. Também se concluiu acerca da importância de se distinguir a personalidade jurídica do sócio e da sociedade, pois se tratam de pessoas distintas, de forma que o sócio não pode se atribuir "dono" da sociedade, pois dela somente é participante. Utilizou-se da técnica da pesquisa bibliográfica e jurisprudencial para instrumentalizar o presente artigo científico, bem como da base lógica indutiva para relatar os resultados do trabalho.

\footnotetext{
${ }^{1}$ Mestre e Doutor em Ciência Jurídica, Pós-Doutor em Direito, Advogado, Professor dos Cursos de Graduação e Pós-Graduação em Direito, na Universidade do Vale do Itajaí - UNIVALI. E-mail: dronconi@terra.com.br.

2 Mestre em Ciência Jurídica, Doutorando em Ciência Jurídica, Advogado, professor do Curso de Graduação em Direito, na UNIVERSIDADE DO VALE DO ITAJAÍ - UNIVALI. E-mail: natan@brfadvogados.com.br.
} 
RONCONI, Diego Richard. BRAGA, Natan Ben-Hur. A propriedade de quotas societárias: alguns de seus desdobramentos jurídicos nas relações privadas. Revista Eletrônica Direito e Política, Programa de Pós-Graduação Stricto Sensu em Ciência Jurídica da UNIVALI, Itajaí, v.11, n.1, 10 quadrimestre de 2016. Disponível em: www.univali.br/direitoepolitica - ISSN 1980-7791.

PAlAVRAS-CHAVE: Quota Societária; Princípio da Autonomia Patrimonial; Pessoa Jurídica.

\section{RESUMEN}

El objeto del presente trabajo es realizar un breve estudio acerca de la propiedad de las cuotas societarias. El objetivo general es identificar el concepto de cuota societaria, así como establecer reflexiones y desdoblamientos de la condición de ser propietario de cuotas societarias en algunas clases jurídicas en el ámbito del derecho civil (obligaciones, contratos, familia y sucesiones) y empresarial (derecho societario). Los objetivos específicos de la pesquisa, confirmados con el estudio, identificaron algunos derechos de orden personal y patrimonial del titular de las cuotas. Entre los derechos de orden patrimonial, se identificó la distribución de lucros societarios, los cuales podrán ser desproporcionales a la participación del socio en la sociedad. También se concluyo acerca de la importancia de distinguirse la personalidad jurídica del socio y de la sociedad, porque se tratan de personas distintas, de forma que el socio no se puede atribuir "dueño" de la sociedad, porque de ella solamente es participante. Se utilizó de la técnica de la pesquisa bibliográfica y jurisprudencial para instrumentalizar el presente artículo científico, así como de la base lógica inductiva para relatar los resultados del trabajo.

PALABRAS-ClAVE: Cuota Societaria; Principio de la Autonomía Patrimonial; Persona Jurídica.

\section{INTRODUÇÃO}

Este artigo objetiva, de forma geral, identificar o significado de Quota Societária, como objetivo específico, estabelecer reflexões e desdobramentos em algumas disciplinas jurídicas no âmbito do direito civil e empresarial, da condição de ser proprietário de tais quotas em uma sociedade empresária. Portanto, tratar-se-á, aqui, somente de sociedades contratuais, e não de sociedades estatutárias (como as sociedades anônimas.

Para tanto, pretendem-se estabelecer as seguintes perguntas de pesquisa:

a) o fato de ser proprietário de uma quota social outorga quais direitos ao seu titular?

b) a distribuição de lucros da sociedade deve ser realizada na exata igualdade do percentual de quotas sociais do seu titular?

c) o fato de ser proprietário de quotas sociais significa que se é "dono" de uma empresa? 
RONCONI, Diego Richard. BRAGA, Natan Ben-Hur. A propriedade de quotas societárias: alguns de seus desdobramentos jurídicos nas relações privadas. Revista Eletrônica Direito e Política, Programa de Pós-Graduação Stricto Sensu em Ciência Jurídica da UNIVALI, Itajaí, v.11, n.1, $1^{\circ}$ quadrimestre de 2016. Disponível em: www.univali.br/direitoepolitica - ISSN 1980-7791.

Tem-se como hipóteses de pesquisa:

a) o fato de ser titular de quotas sociais outorga direitos de natureza pessoal, como a atribuição, perante terceiros, da condição de titular de uma parcela da sociedade na qualidade de sócio; fiscalização dos atos societários; e patrimonial, como a distribuição de lucros societários, bem como, na extinção da sociedade, a divisão do saldo patrimonial da mesma conforme sua participação no contrato social;

b) a distribuição de lucros da sociedade pode ser realizada de forma desigual à participação societária no capital social;

c) ser "sócio" de uma empresa não significa ser o "dono" da sociedade, pois esta se constitui numa pessoa distinta da pessoa dos seus sócios.

Quanto à metodologia, foi utilizada a base lógica Indutiva por meio da pesquisa bibliográfica e no relatório final foi utilizado o método indutivo com as técnicas do referente, da categoria, dos conceitos operacionais e da pesquisa bibliográfica.

\section{O CAPITAL SOCIAL DAS EMPRESAS E A FORMAÇÃo DAS QUOTAS SOCIETÁRIAS}

Quando se inicia uma sociedade empresária, um dos requisitos essenciais consiste na realização de um instrumento chamado "contrato social", ou "estatuto social", a fim de nele constarem os termos que os sócios (ou acionistas) definiram como essenciais para o prosseguimento da sociedade.

O contrato social consiste em um "(...) negócio plurilateral por meio do qual duas ou mais pessoas, naturais ou jurídicas, ajustam entre si a constituição de uma sociedade simples ou empresária" ${ }^{3}$.

No contrato social são definidos vários aspectos envolvendo elementos fundamentais da vida societária, seja na questão pessoal dos sócios entre si, seja

\footnotetext{
${ }^{3}$ MAMEDE, Gladston. Direito Societário: sociedades simples e empresárias. 2. Ed. São Paulo: Atlas, 2007. p. 67.
} 
RONCONI, Diego Richard. BRAGA, Natan Ben-Hur. A propriedade de quotas societárias: alguns de seus desdobramentos jurídicos nas relações privadas. Revista Eletrônica Direito e Política, Programa de Pós-Graduação Stricto Sensu em Ciência Jurídica da UNIVALI, Itajaí, v.11, n.1, 10 quadrimestre de 2016. Disponível em: www.univali.br/direitoepolitica - ISSN 1980-7791.

na relação dos sócios para com a sociedade, seja da sociedade e sócios perante terceiros, identificadas algumas cláusulas obrigatórias nos artigos 46 e 997, do Código Civil

O contrato social, devidamente registrado na Junta Comercial, dá origem a uma nova pessoa: a pessoa jurídica, a qual passa a existir com autonomia patrimonial e independência de seus sócios.

No entanto, tal situação é de difícil compreensão para muitos sócios, ou acionistas (e até mesmo para outros membros da coletividade, como credores), os quais não entendem (ou não querem entender) a distinção das personalidades dos "sócios" e a da sociedade criada. Exemplo disso pode se verificar em situações muito comuns, como o próprio dizer do sócio: "vou à minha empresa", ou "eu tenho uma empresa". Aliás, muitos sócios, acreditando que a sociedade e eles são a mesma coisa, fazem dívidas pessoais com aquisições de roupas, viagens, aquisição de alimentos, com o cartão de crédito da sociedade, e não de suas próprias pessoas, entendendo que a propriedade de um é também do outro. Esta mentalidade é muito perigosa. O Poder Judiciário, nestes termos, já tem identificado uma confusão patrimonial entre as pessoas dos sócios e da sociedade, causando transtornos sérios neste sentido, até com entendimento de distribuição disfarçada de lucros aos sócios ${ }^{4}$.

Esta relação do "ter" a sociedade é que se torna perigoso ao sócio, o qual deverá identificar que o mesmo não "tem" a sociedade, mas uma "quota" dela. Isto implica na compreensão e aceitação de limites entre a sociedade e seus sócios, os quais necessitam compreender que são "quotistas", ou "acionistas", mas não donos, ou proprietários da "empresa".

A palavra "quota", ou "cota", tem o significado de parte, parcela de alguma coisa. No direito societário, a quota está ligada ao capital social da empresa, pois

\footnotetext{
4 "TRIBUTÁRIO. IMPOSTO DE RENDA. PESSOA FÍSICA. DISTRIBUIÇÃO DISFARÇADA DE LUCRO. EMPRÉSTIMO A SÓCIO. 1. O empréstimo concedido pela pessoa jurídica a sócio sem data de vencimento e sem qualquer vantagem para a sociedade, caracteriza distribuição disfarçada de lucro. 2. A tributação deverá atingir a pessoa física que auferiu benefício econômico, na forma do ART-20 INC-9 do DEL-2065/83. 3. Os juros de mora são contados desde a ocorrência do ilícito fiscal. Aplicação do ART-161 do CTN-66. 4. Apelação improvida". (TRF4, AC 96.04.14514-2, Primeira Turma, Relator Fábio Bittencourt da Rosa, DJ 08/07/1998)
} 
RONCONI, Diego Richard. BRAGA, Natan Ben-Hur. A propriedade de quotas societárias: alguns de seus desdobramentos jurídicos nas relações privadas. Revista Eletrônica Direito e Política, Programa de Pós-Graduação Stricto Sensu em Ciência Jurídica da UNIVALI, Itajaí, v.11, n.1, $1^{0}$ quadrimestre de 2016. Disponível em: www.univali.br/direitoepolitica - ISSN 1980-7791.

o capital social (nas sociedades contratuais) é dividido em quotas, ou em ações (nas sociedades estatutárias). Neste sentido, Requião ${ }^{5}$ cita lição do Prof. Barros Leães, para o qual a quota não somente consiste na "(...) entrada, ou contingente, de bens, coisas e valores com o qual um dos sócios contribui ou se obriga a contribuir para a formação do capital social", mas também no "(...) complexo de direitos, poderes, obrigações ou faculdades, que compõe o status do sócio, por força de celebração do contrato social".

Conforme Rocha Filho ${ }^{6}$, não se pode confundir "capital social" com "fundo social", este que se trata da soma de todos os bens da sociedade, inclusive o próprio capital social. A principal função do capital social consiste em constituir:

"(...) o fundo inicial, essencial à existência da sociedade. Serve, porém, a outras finalidades, como, por exemplo, base de cálculo da divisão proporcional dos lucros ou prejuízos; verificação dos resultados finais da sociedade; e, principalmente, como garantia de terceiros, porque a lei não permite a distribuição, entre os sócios, das quantias necessárias para mantê-lo intacto.". Consiste em bem intangível, segundo o autor.

Normalmente se identifica, nos contratos sociais, a seguinte redação:

"Do Capital e das Quotas

Cláusula X - O capital social, de $\mathrm{R} \$ 50.000,00$ (cinquenta mil reais) constituído de 50.000 (cinquenta mil) quotas do valor nominal de $R \$ 1,00$ (um real) cada uma, é subscrito e integralizado pelos sócios, da seguinte forma:

\footnotetext{
${ }^{5}$ REQUIÃO, Rubens. Curso de direito comercial. 25. ed. São Paulo: Saraiva, 2003. v. 1, p. 479..

${ }^{6}$ ROCHA FILHO, José Maria. Curso de direito Comercial: parte geral. 3. Ed. Belho Horizonte, Del Rey, 2004, p. 289-290.
} 
RONCONI, Diego Richard. BRAGA, Natan Ben-Hur. A propriedade de quotas societárias: alguns de seus desdobramentos jurídicos nas relações privadas. Revista Eletrônica Direito e Política, Programa de Pós-Graduação Stricto Sensu em Ciência Jurídica da UNIVALI, Itajaí, v.11, n.1, $1^{0}$ quadrimestre de 2016. Disponível em: www.univali.br/direitoepolitica - ISSN 1980-7791.

a) O sócio JOÃO $X X X$, subscreve 25.000 (vinte e cinco mil) quotas no valor total de $\mathrm{R} \$ 25.000,00$ (vinte e cinco mil reais) e as integraliza neste ato, em moeda corrente nacional.

b) O sócio GUSTAVO YYY, subscreve 25.000 (vinte e cinco mil) quotas no valor total de $\mathrm{R} \$ 25.000,00$ (vinte e cinco mil reais) e as integraliza neste ato, em moeda corrente nacional."

A partir do instante em que se define o quantum do capital social de cada sócio, ou seja, qual será sua participação na sociedade, o investimento particular do sócio estará proporcionalmente ligado a esta participação, como se ilustrou no exemplo acima. No entanto, como se observará a seguir, isto não significa que a distribuição dos lucros será proporcional a esta participação, pois o contrato social poderá prever forma diversa.

Não é incomum realizar-se a transferência de veículos, imóveis e outros bens para a sociedade. No entanto, tais bens deixam de ser "propriedade" do sócio e passam a integrar a "propriedade" da sociedade. Assim, o antigo dono deixa de sê-lo, pois transferiu o bem que integrava seu patrimônio para o patrimônio de outra pessoa: a pessoa jurídica. Saliente-se que, embora este direito de propriedade seja individual, seu exercício deverá ser social ${ }^{7}$.

Portanto, a quota social nada mais é do que uma parcela do Capital Social da empresa, entendendo-se por Capital Social a quantidade de investimento que será necessária para que a sociedade possa funcionar. Este capital poderá se constituir em dinheiro, bens móveis, bens imóveis, direitos de crédito, títulos, ou outros bens que possuam quantificação econômica, a fim de que possam integrar o patrimônio da sociedade.

\footnotetext{
${ }^{7}$ FACHIN, Luiz Edson. Estatuto jurídico do patrimônio mínimo. Rio de Janeiro: Renovar, 2001,
} p. 72. 
RONCONI, Diego Richard. BRAGA, Natan Ben-Hur. A propriedade de quotas societárias: alguns de seus desdobramentos jurídicos nas relações privadas. Revista Eletrônica Direito e Política, Programa de Pós-Graduação Stricto Sensu em Ciência Jurídica da UNIVALI, Itajaí, v.11, n.1, $1^{0}$ quadrimestre de 2016. Disponível em: www.univali.br/direitoepolitica - ISSN 1980-7791.

O sócio que tiver transmitido domínio, posse ou uso de um bem à sociedade, a título de quota societária, responde pela perda deste bem pela sociedade, em decorrência de uma sentença judicial (evicção) e pela solvência do devedor, se tiver transferido algum crédito à sociedade.

Importante salientar que, conforme dispõe o art. 1.055 , parágrafo 20 , do Código Civil, é vedada a contribuição do sócio que consista em prestação de serviços, na sociedade limitada, situação esta admitida nas sociedades simples (art. 997, V, do Código Civil).

As quotas podem ser iguais ou desiguais, cabendo uma ou diversas a cada sócio, sendo indivisível relativamente à sociedade, exceto no que diz respeito à transferência das mesmas, nos termos do disposto no art. 1.056, do Código Civil.

Sendo omisso o contrato, poderá haver a cessão da quota pelo sócio (na forma de doação, permuta, venda etc.), de forma total ou parcial, a outro sócio, independentemente da oitiva dos demais sócios, ou a quem não seja sócio, necessitando, neste caso de, no mínimo, 75\% de aprovação dos demais sócios (art. 1.057, do Código Civil). Tal cessão, no entanto, somente terá eficácia perante a sociedade e terceiros, a partir da averbação do instrumento da cessão, subscrito pelos sócios anuentes, havendo necessidade de modificação do contrato social, respondendo o cedente de forma solidária com o cessionário, perante a sociedade e terceiros pelas obrigações que tinha como sócio, até dois anos após a averbação da modificação do contrato.

Mas, qual a vantagem, então, de se transferir o patrimônio do sócio para outra pessoa, ou seja, a pessoa jurídica que pretende ingressar? Além de se tratar de uma obrigação para aquele que pretende ser sócio de uma sociedade, adiante, observar-se-ão algumas reflexões que poderão influenciar na transferência da propriedade de bens da pessoa do sócio para a sociedade.

\section{O PRINCÍPIO DA AUTONOMIA PATRIMONIAL DA PESSOA JURÍDICA}

Para se entender o princípio da Autonomia Patrimonial da Pessoa Jurídica, é fundamental compreender o significado de "personalidade jurídica" e seu objetivo. Personalidade é uma aptidão que as pessoas têm para adquirir direitos 
RONCONI, Diego Richard. BRAGA, Natan Ben-Hur. A propriedade de quotas societárias: alguns de seus desdobramentos jurídicos nas relações privadas. Revista Eletrônica Direito e Política, Programa de Pós-Graduação Stricto Sensu em Ciência Jurídica da UNIVALI, Itajaí, v.11, n.1, $1^{0}$ quadrimestre de 2016. Disponível em: www.univali.br/direitoepolitica - ISSN 1980-7791.

e assumir obrigações. Difere de "capacidade jurídica", ou "capacidade de direito", que é a "aptidão para exercer direitos e contrair obrigações da capacidade de fato, que é a aptidão 'pessoal' para praticar atos com efeitos jurídicos" ${ }^{\prime 8}$.

O ser humano é considerado "pessoa natural", ou "pessoa física". A personalidade jurídica do homem inicia quando ele nasce com vida, mas a lei protege os direitos daquele que já está no ventre da mãe, mas que ainda não nasceu (conhecido como "nascituro", conforme o art. 2 o, do Código Civil).

Tanto a pessoa natural, ao nascer com vida, bem como a pessoa jurídica (sociedades empresárias, associações, partidos políticos etc.), têm personalidade jurídica. A pessoa jurídica consiste numa invenção legislativa, e seu objetivo consiste em ser uma técnica de separação patrimonial, identificando que seus membros não são titulares nem das obrigações, nem dos direitos que pertencem à pessoa jurídica, tratando-se de patrimônio diverso dos sócios da pessoa jurídica.

Conforme ensina Coelho ${ }^{9}$, sociedade e sócio não são a mesma pessoa:

"No patrimônio dos sócios encontra-se a participação societária, representada pelas quotas da sociedade limitada ou pelas ações da sociedade anônima. A participação societária, no entanto, não se confunde com o conjunto de bens titularizados pela sociedade, nem com uma sua parcela ideal. Trata-se, definitivamente, de patrimônios distintos, inconfundíveis e incomunicáveis os dos sócios e o da sociedade.".

Aqui, cabe uma breve exemplificação do que ocorre com o "empresário individual", a fim de se entender a importância do princípio da autonomia patrimonial da pessoa jurídica. Considera-se empresário individual a pessoa natural que realiza, individualmente e em nome próprio, atos de empresa.

\footnotetext{
${ }^{8}$ VENOSA, Silvio de Salvo. Direito civil: parte geral. 8. ed. São Paulo: Atlas, 2008. p. 141. v. 1.

${ }^{9}$ COELHO, Fábio Ulhoa. Curso de direito comercial: direito de empresa: sociedades. 15. ed. São Paulo: Saraiva, 2011, v. 2. p. 33.
} 
RONCONI, Diego Richard. BRAGA, Natan Ben-Hur. A propriedade de quotas societárias: alguns de seus desdobramentos jurídicos nas relações privadas. Revista Eletrônica Direito e Política, Programa de Pós-Graduação Stricto Sensu em Ciência Jurídica da UNIVALI, Itajaí, v.11, n.1, $1^{\circ}$ quadrimestre de 2016. Disponível em: www.univali.br/direitoepolitica - ISSN 1980-7791.

Inexiste quota societária. No ensinamento de Russo ${ }^{10}$ trata-se de "uma única pessoa é responsável ilimitada nesta modalidade de empresa, pois não terá sócio nenhum e tampouco poderá admitir, transferi-la ou vende-la". Ainda, na lição de Requião ${ }^{11}$ (2003: p. 78), o empresário individual: "(...) é a própria pessoa física ou natural, respondendo os seus bens pelas obrigações que assumiu, quer sejam civis, quer comerciais. A transformação de firma individual em pessoa jurídica é uma ficção do direito tributário, somente para o efeito do imposto de renda $(\ldots)^{\prime \prime}$.

Assim, diversamente das principais Sociedades Empresárias como a sociedade anônima e a sociedade limitada, a responsabilidade do Empresário Individual é ilimitada, não havendo distinção de patrimônios e obrigações. Aliás, não há, sequer, personalidade jurídica do empresário individual.

No entanto, com a entrada em vigor da Lei n. 12.441, de 11 de julho de 2011 a qual acrescentou os artigos 44, VI; 980 e 1.033, do Código Civil, passou a existir a figura da "empresa individual de responsabilidade limitada" (EIRELI). Esta, uma vez constituída, considera-se pessoa jurídica de direito privado, formada por uma só pessoa natural que direciona um patrimônio específico para a empresa individual (pessoa jurídica), a qual tem existência própria, com autonomia patrimonial e responsabilidades próprias. A pessoa natural que constitui a EIRELI é titular de $100 \%$ das quotas do capital social da referida empresa.

Nesta toada, existe grande diferença na escolha de "empresário individual" ou "empresário individual de responsabilidade limitada", pois o simples "empresário individual" não tem autonomia patrimonial, havendo responsabilidade da pessoa natural que é empresária individual por conta das dívidas da empresa individual, e vice-versa, haja vista não existir distinção entre pessoa natural e pessoa jurídica.

Tal distinção interfere, ainda, no caso de falecimento da pessoa natural formadora da empresa individual. Se esta falecer, extingue-se a empresa

\footnotetext{
${ }^{10}$ RUSSO, Luiz R. R. Russo. Como alterar contratos sociais. São Paulo: Atlas, 2004, p. 117.

${ }^{11}$ REQUIÃO, Rubens. Curso de direito comercial, p. 78.
} 
RONCONI, Diego Richard. BRAGA, Natan Ben-Hur. A propriedade de quotas societárias: alguns de seus desdobramentos jurídicos nas relações privadas. Revista Eletrônica Direito e Política, Programa de Pós-Graduação Stricto Sensu em Ciência Jurídica da UNIVALI, Itajaí, v.11, n.1, $1^{0}$ quadrimestre de 2016. Disponível em: www.univali.br/direitoepolitica - ISSN 1980-7791.

individual, com a necessidade de inventário dos bens, direitos e obrigações que fazem parte da empresa individual. No entanto, se a pessoa natural que constituir uma EIRELI falecer, tal situação não ocorrerá. Isto porque, uma vez constituída a EIRELI, a pessoa natural que a forma estabelece a existência de autonomia patrimonial e pessoal da "empresa individual de responsabilidade limitada". Desta forma, se a pessoa natural, titular da EIRELI, vier a falecer, não se extinguirá a pessoa jurídica, havendo, inclusive, responsabilidade limitada de seu titular à integralização do capital social. Com o advento da morte do empresário individual de responsabilidade limitada, o que será objeto de inventário serão os $100 \%$ de suas quotas.

No entanto, importante ressaltar que, atualmente, o princípio da autonomia patrimonial da pessoa jurídica tem sido relativizado em diversas decisões judiciais, não sendo absoluto. Conforme Coelho ${ }^{12}$, tal princípio "(...) tem sua aplicação limitada, atualmente, às obrigações da sociedade perante outros empresários. Se o credor é empregado, consumidor ou o estado, o princípio não tem sido prestigiado pela lei ou pelo juiz". Tal desprestígio decorre do uso fraudulento das sociedades empresárias, com a finalidade de não se cumprir as determinações legais ou contratuais, bem como para satisfação de direitos de titulares de créditos não negociáveis, como aquelas decorrentes de obrigações tributárias e de atos ilícitos e das situações que admitem a desconsideração da personalidade jurídica, a exemplo das situações previstas no art. $50^{13}$, do Código Civil.

\section{AS QUOTAS SOCIETÁRIAS NO ÂMBITO DE ALGUMAS DISCIPLINAS JURÍDICAS CIVIS E EMPRESARIAIS}

12 COELHO, Fábio Ulhoa. Curso de direito comercial: direito de empresa: sociedades, v. 2. pp. $39-41$.

13 "Art. 50. Em caso de abuso da personalidade jurídica, caracterizado pelo desvio de finalidade, ou pela confusão patrimonial, pode o juiz decidir, a requerimento da parte, ou do Ministério Público quando the couber intervir no processo, que os efeitos de certas e determinadas relações de obrigações sejam estendidos aos bens particulares dos administradores ou sócios da pessoa jurídica." 
RONCONI, Diego Richard. BRAGA, Natan Ben-Hur. A propriedade de quotas societárias: alguns de seus desdobramentos jurídicos nas relações privadas. Revista Eletrônica Direito e Política, Programa de Pós-Graduação Stricto Sensu em Ciência Jurídica da UNIVALI, Itajaí, v.11, n.1, $1^{0}$ quadrimestre de 2016. Disponível em: www.univali.br/direitoepolitica - ISSN 1980-7791.

As quotas societárias constituem patrimônio do seu titular. Aliás, elas podem constituir a propriedade de alguém, mas sua posse pode ser outorgada a outrem. Assim, esta titularidade pode ter, a exemplo dos demais bens que compõem o patrimônio de alguém, diversos desdobramentos nas disciplinas jurídicas, cujas implicações em algumas delas passam a ser retratadas em algumas reflexões abaixo dispostas.

\subsection{AS QUOTAS NO DIREITO DAS OBRIGAÇÕES E CONTRATOS}

A obrigação consiste na "(...) relação jurídica transitória de cunho pecuniário, unindo duas (ou mais) pessoas, devendo uma (o devedor) realizar uma prestação à outra (o credor) ${ }^{\prime 14}$. O direito das obrigações, portanto, estuda o conjunto de regras e princípios que determinam esta relação. Poder-se-ia dizer que o direito das obrigações estuda o conteúdo dos contratos, pois estes são manifestações de vontade que buscam gerar certos efeitos jurídicos com a intenção de criar, modificar, ou extinguir direitos e/ou obrigações, tratando-se de um negócio jurídico por excelência.

As quotas societárias consistem em uma participação de alguém no capital social de uma sociedade, com a condição de que esta pessoa cumpra, efetivamente, suas obrigações contratuais. No entanto, para que se complemente a obrigação do sócio, este deverá transferir do seu patrimônio para o patrimônio da sociedade, bens ou direitos que seja titular. Trata-se de uma obrigação denominada de "integralização" do capital social, ou seja, a complementação dos valores comprometidos pelo sócio para com a sociedade.

Caso o sócio não tenha disponibilizado a importância necessária para a complementação da quota societária, restando inadimplente com esta obrigação contratual, ele poderá:

a) ser executado pela sociedade, a fim de que complemente o valor total;

b) ser excluído da sociedade;

\footnotetext{
${ }^{14}$ VENOSA, Silvio de Salvo. . Direito civil: teoria geral das obrigações e teoria geral dos contratos.
} 8. ed. São Paulo: Atlas, 2008. p. 5. v. 2. 
RONCONI, Diego Richard. BRAGA, Natan Ben-Hur. A propriedade de quotas societárias: alguns de seus desdobramentos jurídicos nas relações privadas. Revista Eletrônica Direito e Política, Programa de Pós-Graduação Stricto Sensu em Ciência Jurídica da UNIVALI, Itajaí, v.11, n.1, $1^{0}$ quadrimestre de 2016. Disponível em: www.univali.br/direitoepolitica - ISSN 1980-7791.

c) se tiver integralizado parcialmente a sua quota, poderá, ou ser excluído da sociedade, devolvendo-se a sua quota, com desconto de eventual cláusula penal determinada no Contrato Social; ou poderá ser mantido na sociedade, encontrando-se aí duas soluções: c.1) executando-se o sócio pelo restante que falta para integralização das quotas, mantendo-se o valor do capital social; ou c.2) reduzindo-se o capital social e, consequentemente, reduzindo-se a participação societária do sócio chamado "remisso" (aquele que não integralizou, total ou parcialmente, sua quota societária).

Assim, para que se tenha a condição de sócio, é fundamental que a quota societária esteja integralizada, ou sendo integralizada no decorrer do tempo, conforme for determinado no contrato social (também chamado capital "subscrito", ou seja, aquele que irá, aos poucos, sendo integralizado).

Portanto, aquele sócio que aparece no contrato social, mas que não cumpre totalmente sua parte na integralização de sua quota, ou está em mora com relação à integralização, pode ser entendido como sócio, arcando com as obrigações sociais mas, por restar inadimplente com relação à sociedade, não poderá exigir que a sociedade lhe outorgue direitos. Isto porque, conforme dispõe o art. 476, do Código Civil: "Nos contratos bilaterais, nenhum dos contratantes, antes de cumprida a sua obrigação, pode exigir o implemento da do outro". Assim, se um sócio não tiver integralizado sua parte na quota social e a sociedade tiver lucros para serem divididos entre os sócios, a sociedade não estará obrigada a pagar o sócio remisso, utilizando-se do fundamento da exceção de contrato não cumprido descrita no art. 476, do Código Civil.

As quotas societárias, como bens de propriedade de seu titular, podem ser objeto de cessão gratuita (doação) ou onerosa (compra e venda, permuta), constituindo objetos de contrato. No entanto, existem certas limitações contratuais para que tais transferências possam ocorrer, tais como limitação da cessão das quotas sociais a terceiros não sócios (art. $1.057^{15}$, do Código Civil), a

15 "Art. 1.057. Na omissão do contrato, o sócio pode ceder sua quota, total ou parcialmente, à quem seja sócio, independentemente de audiência dos outros, ou a estranho, se não houver oposição de titulares de mais de um quarto do capital social". 
RONCONI, Diego Richard. BRAGA, Natan Ben-Hur. A propriedade de quotas societárias: alguns de seus desdobramentos jurídicos nas relações privadas. Revista Eletrônica Direito e Política, Programa de Pós-Graduação Stricto Sensu em Ciência Jurídica da UNIVALI, Itajaí, v.11, n.1, $1^{0}$ quadrimestre de 2016. Disponível em: www.univali.br/direitoepolitica - ISSN 1980-7791.

observância do direito de preferência dos demais sócios, conforme determinado no contrato social; a venda ou permuta de quotas sociais para os filhos, devendo-se observar o disposto no art. 496, do Código Civil, sob pena de anulação do negócio jurídico ${ }^{16}$; a doação de quotas, sem que sejam respeitados os termos dos artigos $548^{17}$ e $549^{18}$, do Código Civil, sob pena de nulidade do negócio jurídico.

A condição de "apenhabilidade" e de "penhorabilidade" das quotas societárias encontra na doutrina societária uma séria divergência. Conforme Almeida ${ }^{19}$, autores como Rubens Requião chegam a entender que a penhorabilidade de quotas por execução de dívidas particulares do sócio é retrógrada e ilegal ${ }^{20}$. Alerta Requião ${ }^{21}$ para o fato de que, "Apesar disso, o Decreto n. 1.800/96, no art. 47, parágrafo 20 , estabelece: 'Tratando-se de penhora, sequestro ou arresto de quotas ou de ações, à Junta Comercial competirá, tão-somente, para conhecimento de terceiros, proceder à anotação correspondente, não the cabendo a condição de depositária fiel" (grifado).

Por outro lado, José Eunápio Borges entende que, se a quota é alienável e cessível, pode ser objeto de penhora. Já, para Waldirio Bulgarelli, a quota societária não se constitui um direito de crédito, ou crédito contra a sociedade, constituindo-se uma parte ideal do capital social que dá gênese à uma expectativa de direito do seu recebimento quando houver liquidação societária e se houver saldo para os sócios.

16 "Art. 496. É anulável a venda de ascendente a descente, salvo se os outros descendentes e o cônjuge do alienante expressamente houverem consentido".

17 "Art. 548. É nula a doação de todos os bens sem reserva de parte, ou renda suficiente para a subsistência do doador".

18 "Art. 549. Nula é também a doação quanto à parte que exceder à de que o doador, no momento da liberalidade, poderia dispor em testamento."

${ }^{19}$ ALMEIDA, Amador Paes de. Manual das sociedades comerciais. 10. Ed. São Paulo: Saraiva, 1998. pp. 32-33.

${ }^{20}$ REQUIÃO, Rubens. Curso de direito comercial. 25. ed. São Paulo: Saraiva, 2003. v. 1, p. 485.

${ }^{21}$ REQUIÃO, Rubens. Curso de direito comercial, p. 485. 
RONCONI, Diego Richard. BRAGA, Natan Ben-Hur. A propriedade de quotas societárias: alguns de seus desdobramentos jurídicos nas relações privadas. Revista Eletrônica Direito e Política, Programa de Pós-Graduação Stricto Sensu em Ciência Jurídica da UNIVALI, Itajaí, v.11, n.1, $1^{0}$ quadrimestre de 2016. Disponível em: www.univali.br/direitoepolitica - ISSN 1980-7791.

No entanto, para Rocha Filho ${ }^{22}$, as quotas societárias não são materializadas em título ou certificado, a exemplo das ações. Estas são bens móveis, mas as quotas, para o referido autor, consistem em "direito de crédito futuro", pois, quando realizada a contribuição para a que se forme o capital social, "(...) o sócio transfere para a sociedade a propriedade, o uso ou o usufruto daqueles seus bens e passa a gozar, em função dessa transferência, dos resultados líquidos do investimento. (...) A rigor, pois, as 'quotas' pertencem à sociedade; não aos seus sócios". Tal posicionamento já decorre das lições de Carvalho de Mendonça e de Rubens Requião ${ }^{23}$, que também classificam a quota social como um "direito de crédito futuro", haja vista que,:

"(...) ao contribuir para a formação do capital social o sócio transfere seus cabedais e passa a gozar apenas dos resultados líquidos desse investimento. Seu direito a tais cabedais, que integram o patrimônio da sociedade e passam a pertencer-Ihe, configura uma expectativa de crédito futuro, que se vai consolidar se remanescer algum valor na final liquidação da sociedade."

Ainda, para Rocha Filho $^{24}$, nem é possível penhora, nem penhor de quotas, entendendo que só poderia ser possível a penhora se elas fossem transferidas livremente para terceiros. Admite, então, que a quota só poderá ser penhorada "se o contrato contiver cláusula permitindo sua cessão a terceiros, sem a anuência dos demais sócios; $(\ldots)^{\prime \prime}$.

Quanto ao "penhor" de quotas, Rocha Filho ${ }^{25}$ entende ser "impossível" porque o art. 1.431 do Código Civil estabelece que "constitui-se o penhor pela transferência efetiva da posse que, em garantia do débito ao credor ou a quem o represente, faz o devedor, ou alguém por ele, de uma coisa móvel, suscetível da

\footnotetext{
22 ROCHA FILHO, José Maria. Curso de direito Comercial: parte geral, p. 305.

${ }^{23}$ REQUIÃO, Rubens. Curso de direito comercial, p. 480.

${ }^{24}$ ROCHA FILHO, José Maria. Curso de direito Comercial: parte geral. p. 307.

${ }^{25}$ ROCHA FILHO, José Maria. Curso de direito Comercial: parte geral, pp. 308-309.
} 
RONCONI, Diego Richard. BRAGA, Natan Ben-Hur. A propriedade de quotas societárias: alguns de seus desdobramentos jurídicos nas relações privadas. Revista Eletrônica Direito e Política, Programa de Pós-Graduação Stricto Sensu em Ciência Jurídica da UNIVALI, Itajaí, v.11, n.1, $1^{\circ}$ quadrimestre de 2016. Disponível em: www.univali.br/direitoepolitica - ISSN 1980-7791.

alienação". Entende o referido autor que somente é possível ser empenhado os direitos decorrentes da quota, mas não a própria quota.

Crê-se, no entanto, ser perfeitamente admissível o "penhor" das quotas societárias, isto é, que sejam dadas em garantia de alguma obrigação, bem como a "penhora" das referidas quotas (nas sociedades de capital), na hipótese de dívida particular de sócio executada por seu credor, nos termos descritos no art. $1.026^{26}$, parágrafo único, do Código Civil, além do que, parece-me, compartilhando do entendimento de José Eunápio Borges, o que é alienável e cessível, pode ser objeto de penhora. No entanto, para que tal cessão possa ocorrer, é fundamental que se conheça o contrato social, a fim de se conhecer os limites e termos possíveis desta cessão, pois, se o contrato social não o permitir (sociedade intuitu personae), ou outras limitações que estabeleçam esta cessão (como as do art. 1.057, do Código Civil, ou outras estabelecidas pelas partes, como a cláusula de impenhorabilidade de quotas sociais, possível diante do art. 649, I, do $\left(\mathrm{CPC}^{27}\right)$, estas é que deverão prevalecer. Assim, não é incomum

26 "Art. 1.026. O credor particular de sócio pode, na insuficiência de outros bens do devedor, fazer recair a execução sobre o que a este couber nos lucros da sociedade, ou na parte que the tocar em liquidação.

Parágrafo único. Se a sociedade não estiver dissolvida, pode o credor requerer a liquidacão da quota do devedor, cujo valor, apurado na forma do art. 1.031, será depositado em dinheiro, no juízo da execução, até noventa dias após aquela liquidação." (grifado).

27 Neste sentido, importante a referência à seguinte decisão jurisprudencial: "'AGRAVO DE INSTRUMENTO. EXECUÇÃO. SOCIEDADE LIMITADA. PENHORA DE QUOTAS SOCIAIS. CLÁUSULA DE IMPENHORABILIDADE POR DÍVIDAS PARTICULARES DE SÓCIOS. ENTIDADE FAMILIAR. SOCIEDADE INSTITUÍDA INTUITU PERSONAE. POSSIBILIDADE DE QUEBRA DA AFFECTIO SOCIETATIS. EXEGESE DO ART. 1.026 C/C ART. 1.053, AMBOS DO NOVO CÓDIGO CIVIL. INTELIGÊNCIA DO ART. 591 C/C ART. 648 E ART. 649, I, TODOS DO CPC. RECURSO CONHECIDO E PROVIDO. Havendo cláusula expressa apontada em contrato social, há mais de 25 anos, acerca da impenhorabilidade das quotas da sociedade de responsabilidade limitada por dívidas particulares dos seus sócios, máxime em se tratando de entidade de caráter familiar, impossível recair sobre elas penhora judicial, sob pena de violação dos princípios da livre estipulação e da boa-fé.

Admitir a penhora em hipótese como esta significa nada menos do que proferir decisão manifestamente contrária à regra de exceção insculpida no art. 649, I, do CPC, permissiva de gravame através de cláusula de impenhorabilidade por ato voluntário dos interessados.

Ademais, apenas para argumentar, se alienada as cotas do sócio agravante, perderia a sociedade o seu caráter de entidade familiar, assim conservada há mais de cinco lustros, pondo em risco a tão decantada affectio societatis merecedora de ser preservada.

Igualmente, não se perca de vista regra de direito positivado e máxima jurídica orientadora de eqüidade: "Na aplicação da lei, o juiz atenderá aos fins sociais e as exigências do bem comum" (art. $5 .^{\circ}$ da LICC). 
RONCONI, Diego Richard. BRAGA, Natan Ben-Hur. A propriedade de quotas societárias: alguns de seus desdobramentos jurídicos nas relações privadas. Revista Eletrônica Direito e Política, Programa de Pós-Graduação Stricto Sensu em Ciência Jurídica da UNIVALI, Itajaí, v.11, n.1, $1^{\circ}$ quadrimestre de 2016. Disponível em: www.univali.br/direitoepolitica - ISSN 1980-7791.

observar-se a doação; a venda; o arrolamento de quotas societárias como bem do falecido, ou seja, o que se transfere para terceiros, nestes casos, são as quotas, e não só seus direitos. Aliás, ensina Requião ${ }^{28}$ : "Seja de que natureza jurídica for a quota, posição contratual, direito ou bem imaterial, dúvida não existe de que pode ser ela objeto de contrato de cessão".

Contudo, ressalta Mamede ${ }^{29}$ que, nas sociedades intuitu personae, a penhora de quota societária deverá ocorrer na ausência de outros bens do devedor. No entanto, caso não haja outros bens suficientes à execução, a penhora deverá ser realizada, preferencialmente, sobre a participação do sócio devedor nos lucros sociais, não incidindo a penhora sobre a sua quota.

Para que a quota societária ofertada em garantia valha em desfavor de terceiros, o contrato deveria estar arquivado e averbado no Registro Público de Empresas Mercantis para dar oponibilidade perante terceiros (Junta Comercial) e Cartório de Títulos e Documentos (que se entende facultativo, a teor do art. 144 da Lei no 6015, de 1973, que contempla o penhor como ato registrável no Registro de Títulos e Documentos). Esta operação (garantia de quotas societárias pelo sócio) não tornaria aquele que tem a garantia das quotas como "sócio" da sociedade, mas como mero titular de garantia de eventual inadimplemento do contrato que possui as quotas como garantia.

\subsection{AS QUOTAS NO DIREITO SOCIETÁRIO}

Entende-se como direito societário é o ramo jurídico que estuda as relações de duas ou mais pessoas que reúnem seus esforços e patrimônio com o objetivo de constituir uma sociedade, a qual poderá ter, ou não, finalidade econômica. Neste estudo, concentrar-se-á a atenção no direito societário na parte que trata acerca

Em arremate, a hipótese vertente há de ser interpretada sob a luz do novo Código Civil, artigo $1.026 \mathrm{c} / \mathrm{c}$ art. 1.053, concluindo-se que as constrições judiciais incidirão não sobre as cotas sociais, mas sim sobre o que couber ao devedor nos lucros da sociedade, ou na parte que lhe tocar em liquidação. (Agravo de Instrumento n o 2005.022632-4, da Comarca de Blumenau. Relator: Des. Joel Figueira Júnior. Data da decisão: 31/01/2006. Publicação no DJC n 011.847 , edição de 17/02/2006, p. 16).

${ }^{28}$ REQUIÃO, Rubens. Curso de direito comercial, v. 1, p. 480.

29 MAMEDE, Gladston. Direito empresarial brasileiro: direito societário: sociedades simples e empresárias. 2. Ed. São Paulo, Atlas, 2007. v. 2, p. 143. 
RONCONI, Diego Richard. BRAGA, Natan Ben-Hur. A propriedade de quotas societárias: alguns de seus desdobramentos jurídicos nas relações privadas. Revista Eletrônica Direito e Política, Programa de Pós-Graduação Stricto Sensu em Ciência Jurídica da UNIVALI, Itajaí, v.11, n.1, $1^{0}$ quadrimestre de 2016. Disponível em: www.univali.br/direitoepolitica - ISSN 1980-7791.

das sociedades empresárias, ou seja, naquelas sociedades que têm por escopo a finalidade lucrativa-econômica, especialmente as sociedades limitadas e sociedades anônimas, mais comuns.

No instante em que a pessoa natural ou jurídica assina o contrato social, confirmando sua participação na sociedade, e o contrato social retorna com a aprovação do Registro Público (Junta Comercial, no caso, sem diligências a serem realizadas), tal pessoa já adquire a condição de sócia, independentemente de integralização de sua quota no capital social.

A pessoa que agora já integra a sociedade na condição de sócia passa a ter direitos (distribuição de lucros, fiscalização da sociedade, direito de recesso, participação no saldo da sociedade, caso liquidada, etc.) e obrigações (integralização da quota societária, dever de lealdade, etc.).

Dependendo do tipo societário escolhido, se sociedade de responsabilidade limitada ou ilimitada, o patrimônio particular do sócio poderá, ou não, ser responsabilizado por dívidas da sociedade. Aliás, neste sentido, imagine-se um sócio que tenha integrado a sociedade em data de 10/06/2014 e, embora conste como sócio da sociedade no Contrato Social, não tenha nela integralizado sua quota do capital social. Se, um mês após o seu ingresso, for excluído, venha a falecer ou se retire da sociedade, poderá contra si ter atribuídos todos os efeitos da qualidade de sócio, inclusive os efeitos descritos no art. 1.032, do Código Civil, que determina a responsabilidade do sócio pelas obrigações da sociedade, nos seguintes termos:

\footnotetext{
"Art. 1.032. A retirada, exclusão ou morte do sócio, não o exime, ou a seus herdeiros, da responsabilidade pelas obrigações sociais anteriores, até dois anos após averbada a resolução da sociedade; nem nos dois primeiros casos, pelas posteriores e em igual prazo, enquanto não se requerer a averbação.".
}

Desta forma, integralizada, ou não, a quota social, o sócio que se afasta da sociedade pelos casos anteriormente descritos assume as obrigações da sociedade, ainda que efêmera sua participação na mesma. 
RONCONI, Diego Richard. BRAGA, Natan Ben-Hur. A propriedade de quotas societárias: alguns de seus desdobramentos jurídicos nas relações privadas. Revista Eletrônica Direito e Política, Programa de Pós-Graduação Stricto Sensu em Ciência Jurídica da UNIVALI, Itajaí, v.11, n.1, $1^{0}$ quadrimestre de 2016. Disponível em: www.univali.br/direitoepolitica - ISSN 1980-7791.

Um aspecto importante a ser ressaltado no que diz respeito à propriedade de quota societária é o que diz respeito à distribuição de lucros entre os sócios nas sociedades empresárias.

Conforme determina o art. 1.007, do Código Civil:

\begin{abstract}
"Art. 1.007. Salvo estipulação em contrário, o sócio participa dos lucros e das perdas, na proporção das respectivas quotas, mas aquele, cuja contribuição consiste em serviços, somente participa dos lucros na proporção da média do valor das quotas." (grifado).
\end{abstract}

Por esta disposição, portanto, nas sociedades empresárias, nem sempre a participação nos lucros e perdas será exatamente na proporção das respectivas quotas, pois o artigo permite que seja tratado de forma diferente ("salvo estipulação em contrário"). Portanto, se houvesse no contrato social de uma sociedade com dois sócios, uma cláusula prevendo que o sócio que é titular de $50 \%$ das quotas societárias reste com $80 \%$ dos lucros e perdas sociais, e o outro, titular dos demais $50 \%$ das quotas reste com $20 \%$ dos lucros e perdas da sociedade, seria perfeitamente legal, pois tal desproporcionalidade é juridicamente possível.

Não é incomum a situação em que uma pessoa pretende capitanear a sociedade empresária, mas, como sociedade que pretende instituir, necessita de outra pessoa. Para isso, a parte interessada outorga à outra, por exemplo, $0,5 \%$ do capital social da sociedade, a fim de que a mesma somente empreste seu nome para que a sociedade seja instituída. Primeiro que, como visto, aquele que ingressa na sociedade, ainda com uma ínfima participação nas quotas societárias, já adquire a qualidade de sócio, com todos os seus efeitos. Segundo, que este sócio que tem participação ínfima tem direito de exigir o pagamento de sua participação societária nos lucros sociais, sendo nula qualquer cláusula que afaste qualquer sócio da participação dos lucros e das perdas (art. 1.008, do Código Civil). 
RONCONI, Diego Richard. BRAGA, Natan Ben-Hur. A propriedade de quotas societárias: alguns de seus desdobramentos jurídicos nas relações privadas. Revista Eletrônica Direito e Política, Programa de Pós-Graduação Stricto Sensu em Ciência Jurídica da UNIVALI, Itajaí, v.11, n.1, 10 quadrimestre de 2016. Disponível em: www.univali.br/direitoepolitica - ISSN 1980-7791.

As participações societárias têm grande aplicação no direito de família e sucessório. No direito de família, pode ser aplicado desde a eventual comunicação ao outro cônjuge ou companheiro, em virtude do regime matrimonial adotado (pois se trata de bem que pode fazer parte do patrimônio amealhado), até a indisponibilidade, pelo curador ou tutor do sócio incapaz, de realizar a transferência da propriedade das referidas quotas a terceiros, salvo no caso de autorização judicial, conforme determinam os artigos $1.748^{30}$ e $1.781^{31}$, do Código Civil.

Já, no âmbito do direito das sucessões, igualmente o regime matrimonial de bens adotado pelos cônjuges ou companheiros identificará se haverá, ou não, a participação do supérstite nas referidas quotas. Ressalte-se que, embora as quotas sociais sejam consideradas bens móveis, para efeitos de sucessão aberta, são tidas como bens imóveis, em razão do disposto no art. 80, II, do Código Civil $^{32}$ e, neste ponto, ensina Gonçalves ${ }^{33}$ :

"O direito abstrato à sucessão aberta é considerado bem imóvel, ainda que os bens deixados pelo de cujus sejam todos móveis. Neste caso, o que se considera imóvel não é o direito aos componentes da herança, mas o direito a esta, como uma unidade. A lei não cogita das coisas que estão na

30 "Art. 1.748. Compete também ao tutor, com autorização do juiz:

$(\ldots)$

IV - vender-Ihe os bens móveis, cuja conservação não convier, e os imóveis nos casos em que for permitido".

31 "Art. 1.781. As regras a respeito do exercício da tutela aplicam-se ao da curatela, com a restrição do art. 1.772 e as desta Seção."

32 "Art. 80. Consideram-se imóveis para os efeitos legais:

$(\ldots)$

II- o direito à sucessão aberta".

33 GONÇALVES, Carlos Roberto. Direito civil brasileiro. 7. Ed. São Paulo: Saraiva, 2009. p. 252, v. 1 . 
RONCONI, Diego Richard. BRAGA, Natan Ben-Hur. A propriedade de quotas societárias: alguns de seus desdobramentos jurídicos nas relações privadas. Revista Eletrônica Direito e Política, Programa de Pós-Graduação Stricto Sensu em Ciência Jurídica da UNIVALI, Itajaí, v.11, n.1, $1^{\circ}$ quadrimestre de 2016. Disponível em: www.univali.br/direitoepolitica - ISSN 1980-7791.

herança, mas do direito a esta. Somente depois da partilha é que se poderá cuidar dos bens individualmente."

Da mesma forma, com bem de propriedade do sócio, este poderá legar as quotas societárias através de testamento, observando-se, no entanto, o disposto no art. 1.789, do Código Civil, o qual determina que, se houver herdeiros necessários (ascendente, descendente ou cônjuge), o testador só poderá dispor da metade da herança.

Por vezes se fala em "planejamento sucessório". Este planejamento, normalmente, está vinculado a certos benefícios de ordem tributária, não sendo incomum a criação de sociedades empresárias estabelecidas entre casais e/ou filhos. Nestas sociedades, normalmente tidas como "administradoras de bens próprios", busca-se transferir a titularidade de bens, até então de propriedade (ou posse) de seus sócios, para a sociedade, na forma de integralização do capital social. Desta forma, o casal, v.g., deixa de ser titular dos bens transferidos como integralização das quotas do capital social (veículos, máquinas, casas, terrenos, apartamentos etc.) e passa a ser titular, apenas, das quotas societárias.

$\mathrm{Na}$ eventualidade de falecimento de um dos sócios, então, serão objeto de inventário apenas as quotas societárias, e não os demais bens que passaram a integrar a sociedade, pois, com a integralização das quotas, estes bens agora são da sociedade, e não dos sócios, o que torna mais simples a confecção do inventário.

No entanto, em tais sociedades, é comum que os casais integralizem todos os bens que integravam seu patrimônio, na sociedade. Entende-se tal situação um tanto receosa. Isto porque, diante das variáveis econômicas (e da própria vida), imagine-se que o casal transferiu, juntamente com os demais bens de seu patrimônio, também a casa ou apartamento onde moram. Tal imóvel já não pertence mais ao casal. Se, por alguma circunstância, for atingida, judicialmente, a sociedade administradora de bens que o casal passou a integrar, se o imóvel em que reside o casal for atingido, direta ou indiretamente, por dívidas da sociedade, o casal não poderá mais alegar a condição de bem de família para 
RONCONI, Diego Richard. BRAGA, Natan Ben-Hur. A propriedade de quotas societárias: alguns de seus desdobramentos jurídicos nas relações privadas. Revista Eletrônica Direito e Política, Programa de Pós-Graduação Stricto Sensu em Ciência Jurídica da UNIVALI, Itajaí, v.11, n.1, $1^{\circ}$ quadrimestre de 2016. Disponível em: www.univali.br/direitoepolitica - ISSN 1980-7791.

pleitear a desconstituição da penhora sobre esta casa ou apartamento em que residem, pois já não são mais "de família", mas da sociedade.

Por tais razões, sugere-se que o imóvel que seja o domicílio do casal não integre o patrimônio da sociedade administradora de bens que os mesmos constituíram, pois, na eventualidade de penhora daquele local, poderão se utilizar dos benefícios do Bem de Família, previstos na Lei n. 8.009/90.

Outra circunstância muito comum é a de os pais constituírem uma sociedade empresária e, na sequência, realizarem a transferência das quotas societárias para seus filhos, mas reservando-se os pais no direito de usufruto vitalício das mesmas. Desta forma, os pais não são mais proprietários das quotas, mas meros usufrutuários, podendo, inclusive, retirar os frutos das quotas (lucros) para si, somente tendo impedimento para a disponibilização das quotas a terceiros por qualquer outro meio de cessão das mesmas.

\section{CONSIDERAÇÕES FINAIS}

Diante das considerações realizadas no presente estudo, observou-se que o direito de propriedade sobre a quota social impõe ao seu titular atenção para diversas situações quando se tiver a intenção de disponibiliza-la. A atenção maior se dará no próprio Contrato Social e nas eventuais alterações do mesmo, nos quais se poderá identificar certas limitações, tais como o direito de preferência dos demais sócios; a condição do tratamento da sociedade (se de pessoas, ou de capital), impedindo ou aceitando o ingresso de terceiros na sociedade; a possibilidade, ou não, de oferta das quotas societárias como garantias pessoais dos sócios, ou mesmo da penhora das próprias quotas etc..

Observou-se que o titular de quotas societárias tem direitos de natureza pessoal, como a sua identificação, perante terceiros, da condição de titular de uma parcela da sociedade, atribuindo-se a condição de sócio; fiscalização dos atos societários, e patrimonial, como a distribuição de lucros societários, bem como, na extinção da sociedade, a divisão do saldo patrimonial da mesma conforme sua 
RONCONI, Diego Richard. BRAGA, Natan Ben-Hur. A propriedade de quotas societárias: alguns de seus desdobramentos jurídicos nas relações privadas. Revista Eletrônica Direito e Política, Programa de Pós-Graduação Stricto Sensu em Ciência Jurídica da UNIVALI, Itajaí, v.11, n.1, $1^{0}$ quadrimestre de 2016. Disponível em: www.univali.br/direitoepolitica - ISSN 1980-7791.

participação no contrato social, confirmando-se, desta forma, a primeira hipótese de pesquisa.

Também se viu que os lucros societários podem ser distribuídos de forma desigual ao percentual de quotas societárias no capital social, desde que tal situação conste, de forma expressa, no Contrato Social, a teor do disposto no art. 1.007, do Código Civil. Desta forma, a segunda hipótese também restou confirmada.

Quando se é titular de uma quota societária, significa que se é "sócio" da sociedade que se está participando, mas não significa ser proprietário "da sociedade", pois, pelo princípio da autonomia patrimonial da pessoa jurídica, e da personalidade jurídica própria da pessoa jurídica da sociedade, esta se trata de um ente diverso de seus sócios, com direitos e obrigações próprios. Com isto, também confirmou-se a terceira hipótese de pesquisa.

A abordagem acerca da titularidade das quotas societárias aqui estudada, ainda que delimitada em algumas áreas do Direito Civil e Empresarial, ainda assim não se esgotam em si mesmas. Além disso, existem as demais abordagens em outras disciplinas jurídicas, como o Direito Tributário, o Direito do Trabalho, o Direito Administrativo e Ambiental, nas quais a titularidade da quota societária também pode ter implicações diversas, especialmente no que diz respeito à questão da responsabilidade dos respectivos titulares pelas obrigações da sociedade.

\section{REFERÊNCIAS BIBLIOGRÁFICAS}

ALMEIDA, Amador Paes de. Manual das sociedades comerciais. 10. Ed. São Paulo: Saraiva, 1998.

COELHO, Fábio Ulhoa. Curso de direito comercial: direito de empresa: sociedades. 15. ed. São Paulo: Saraiva, 2011, v. 2.

COELHO, Fábio Ulhoa. Curso de direito comercial: direito de empresa: sociedades, v. 2.

FACHIN, Luiz Edson. Estatuto jurídico do patrimônio mínimo. Rio de Janeiro: Renovar, 2001. 
RONCONI, Diego Richard. BRAGA, Natan Ben-Hur. A propriedade de quotas societárias: alguns de seus desdobramentos jurídicos nas relações privadas. Revista Eletrônica Direito e Política, Programa de Pós-Graduação Stricto Sensu em Ciência Jurídica da UNIVALI, Itajaí, v.11, n.1, 10 quadrimestre de 2016. Disponível em: www.univali.br/direitoepolitica - ISSN 1980-7791.

GONÇALVES, Carlos Roberto. Direito civil brasileiro. 7. Ed. São Paulo: Saraiva, 2009. v. 1.

MAMEDE, Gladston. Direito empresarial brasileiro: direito societário: sociedades simples e empresárias. 2. Ed. São Paulo, Atlas, 2007. v. 2.

PASOLD, César Luiz. Prática da pesquisa jurídica: ideias e ferramentas úteis para o pesquisador do direito. 6. ed. Florianópolis: OAB, 2002.

REQUIÃO, Rubens. Curso de direito comercial. 25. ed. São Paulo: Saraiva, 2003. v. 1.

ROCHA FILHO, José Maria. Curso de direito Comercial: parte geral. 3. Ed. Belho Horizonte, Del Rey, 2004.

RUSSO, Luiz R. R. Russo. Como alterar contratos sociais. São Paulo: Atlas, 2004.

TRIBUNAL DE JUSTIÇA DO ESTADO DE SANTA CATARINA. Agravo de Instrumento n 0 2005.022632-4, da Comarca de Blumenau. Relator: Des. Joel Figueira Júnior. Data da decisão: 31/01/2006. Publicação no DJC $n$ o 11.847, edição de 17/02/2006, p. 16.

VENOSA, Silvio de Salvo. Direito civil: teoria geral das obrigações e teoria geral dos contratos. 8. ed. São Paulo: Atlas, 2008. v. 2.

VENOSA, Silvio de Salvo. Direito civil: parte geral. 8. ed. São Paulo: Atlas, 2008. V. 1 .

Submetido em: Dezembro de 2015.

Aprovado em: Fevereiro 2016. 